\title{
Analisis Dampak Pandemi COVID 19 Terhadap Pemasaran Online di Kecil dan Usaha Menengah (UMKM)
}

\author{
Rahmi Hajriyanti ${ }^{1}$, Rizaldi Akbar ${ }^{2 *}$ \\ 1,2 Program Studi Manajemen Informatika, AMIK Indonesia, Kota Banda Aceh, \\ Provinsi Aceh, Indonesia.
}

\begin{abstract}
Abstrak. Penelitian ini bertujuan untuk menganalisis dampak pandemi COVID 19 terhadap pemasaran online bagi Usaha Mikro, Kecil, dan Menengah (UMKM). Metode penelitian yang digunakan dalam penelitian ini adalah deskriptif analisis dan termasuk dalam jenis penelitian kepustakaan. Luaran dari penelitian ini adalah jurnal nasional dan internasional. Penelitian ini diharapkan dapat meningkatkan pertumbuhan UMKM melalui pemasaran online. Hasil kajian literatur menyimpulkan babwa pandemi virus corona telab memberikan dampak yang signifikean bagi para pelaku usaha di selurub dunia, termasuk di Indonesia. Sebagian besar pelaku usaha terpaksa menghentikan kegiatan usahanya, karena kebijakan yang dikeluarkan oleh pemerintah. Keadaan ini berdampak pada penurunan turnover. Namun di sisi lain terjadi peningkatan transaksi penjualan online yang cukup signifikan sehingga dapat menjadi peluang bagi tumbubnya UMKM dengan mengoptimalkan pemasaran online.
\end{abstract}

Kata kunci: Pandemic; COVID-19; Online Marketing; UMKM.

\begin{abstract}
This study aims to analyze the impact of the COVID 19 pandemic on online marketing for Micro, Small, and Medium Enterprises (MSMEs). The research method used in this research is descriptive analysis and is included in the type of library research. The output of this research is national and international journals. This research is expected to increase the growth of MSMEs through online marketing. The results of a literature review concluded that the coronavirus pandemic has had a significant impact on business actors around the world, including in Indonesia. Most business actors are forced to stop their business activities, because of policies issued by the government. This situation has an impact on reducing turnover. But on the other hand, there is a significant increase in online sales transactions so that it can become an opportunity for the growth of MSMEs by optimizing online marketing.
\end{abstract}

Keywords: Pandemic; COVID-19; Online Marketing; MSME.

*Author. Email: rahmihajriyanti@amikindonesia.ac.id 1, rizaldikbar@amikindonesia.ac.id 2*.

DOI: https://doi.org/10.35870/emt.v5i2.450

Received: 7 July 2021, Revision: 28 August 2021, Accepted: 1 September 2021.

Print ISSN: 2579-7972; Online ISSN: 2549-6204.

Copyright@ 2021. Published by Lembaga Otonom Lembaga Informasi dan Riset Indonesia (KITA INFO dan RISET). 


\section{Pendahuluan}

Pandemi virus corona berdampak signifikan terhadap bisnis di seluruh dunia. Termasuk di Indonesia. Sebagian besar pelaku usaha terpaksa menghentikan kegiatan usahanya, karena kebijakan yang dikeluarkan oleh pemerintah. Ini situasi berdampak pada pengurangan turn-over. Tapi, di sisi lain, ada peningkatan yang signifikan dalam penjualan online transaksi. CNN Indonesia mengutip pernyataan Menteri Koperasi dan Kecil Menengah Badan Usaha (UKM) Teten Masduki yang mengatakan, transaksi penjualan online meningkat $350 \%$ di tengah pandemi Covid-19 pandemi.

Menurut laporan BPS (2019), pada tahun 2019 sebanyak 15,08\% bisnis di Indonesia dijalankan online, sisanya $84,92 \%$ masih offline. Namun, berdasarkan hasil penelitian terbaru yang diungkapkan oleh Kementerian Koordinator Bidang Perekonomian, selama pandemi Covid-19 terjadi peningkatan hingga lebih dari 300 ribu pengusaha baru memasuki ranah online. Peningkatan ini cukup beralasan, karena Adanya pembatasan sosial dan berkurangnya aktivitas di luar rumah mendorong masyarakat untuk lebih konsumtif dalam melakukan transaksi melalui platform digital. Ahmad M Ramli, Direktur Jenderal Penyelenggaraan Pos dan Informatika (PPI) Kominfo, mengatakan selama pandemi Covid19 jumlah transaksi toko online meningkat 400 persen dan diprediksi terus di new normal, platform marketplace akan mendapatkan persaingan dari peritel besar hingga minimarket yang juga membuka layanan online untuk pengiriman. Sementara itu, Ketua Umum Asosiasi Indonesian Express, Post dan Perusahaan Jasa Pelayaran Logistik (Asperindo), Mohammad Feriadi, mengakui adanya peningkatan permintaan pengiriman barang akibat pergeseran pemesanan barang melalui platform online.

\section{Literature Review}

\section{Pandemi Covid-19}

Sejak kasus pertama infeksi penyakit corona virus atau dikenal Covid-19 pada tahun 2019 di berbagai wilayah asia timur dan barat menjadikan sebagian orang melakukan pengujian dan memperluas definisi dari pandemic Covid-19 (Tosepu et al, 2020). Di Indonesia pada tahun 2020 juga memulai menyelidiki dengan penelitian yang melibatkan berbagai tim riset serta berkolaborasi dengan berbagai bidang ilmu mengingat jumlah kasus semakin tinggi setiap bulannya. Virus corona baru atau sebutan medis disebut severe acute respiratory syndrome coronavirus 2 (SARS-CoV-2) telah mencemari dunia (Sverzellati et al, 2020), virus ini berasal dari China dan telah menginfeksi banyak orang Dunia (Simonetti et al, 2020) termasuk di Indonesia sejak Maret 2020 (Aliyyah et al, 2020). Virus SARS-CoV-2 dapat menyebabkan berbagai tingkat kerusakan sel (Pfefferbaum \& North, 2020; Ciotti et al, 2020). Difusi yang cepat dan efek dari virus ini digolongkan sebagai ancaman global dan ditetapkan sebagai pandemi oleh Organisasi Kesehatan Dunia pada 11 Maret, 2020 (Sultan et al, 2020; Rodriguez-Morales et al, 2020).

\section{Pemasaran Online}

Pemasaran telah mengalami transformasi secara signifikan di Indonesia, beredarnya e-commerce dan transaksi digital di Indonesia telah membawa dampak budaya belanja yang sebelumnya dilakukan secara tatap muka sekarang mereka berbelanja dan membeli secara online (Opreana \& Vinerean, 2015). Pemasaran tradisional tidak lagi menjadi pilihan yang layak (Bostanshirin, 2014), sehingga memunculkan perkembangan pemasaran baru, yaitu digital inbound marketing (Patrutiu-Baltes, 2016). Jenis pemasaran baru ini difokuskan untuk menarik konsumen yang yang memilih untuk berinteraksi dengan perusahaan tertentu yang memberi mereka sesuatu yang bermanfaat.

COVID-19 telah mempengaruhi kehidupan sehari-hari semua orang, termasuk para pengecer, distributor baik dilakukan secara offline dan online. Dalam aspek ini, bisnis rentan untuk melakukan transformasi substansial (Kim, 2020). Kebanyakan manajemen operasional tempat kerja telah dilakukan secara virtual (Pantelimon, Georgescu, \& Posedaru, 2020). Pengaruh transformasi digital pada produktivitas dan budaya perusahaan telah dipelajari secara ekstensif (Galhotra \& Dewan, 2020). Perubahan di masa pandemi Covid-19 telah membawa arah pedagang dan konsumen untuk melakukan transaksi secara digital dan 
merupakan cara untuk memulihkan dan meningkatkan penjualan setelah COVID-19.

\section{Usaha Mikro, Kecil, dan Menengah (UMKM)}

Usaha Mikro, Kecil, dan Menengah (UMKM) merupakan istilah umum yang mengacu pada seseorang atau usaha ekonomi produktif baik yang dimiliki perseorangan atau badan usaha sesuai dengan kriteria yang ditetapkan dengan Undang-undang Nomor 20 Tahun 2008 Tentang Usaha Mikro, Kecil, dan Menengah. Berbagai definisi terkait UMKM telah menyebabkan beragam pendekatan oleh Pemerintah dan organisasi lain di berbagai negara (Jahanshahi et al, 2011). Mendefinisikan sektor UKM, dan khususnya usaha kecil, cukup sulit, karena ada perbedaan dalam apa yang tepat untuk digambarkan sebagai "kecil" di industri yang berbeda. Kriteria utama yang mendominasi untuk menentukan sektor UMKM adalah jumlah karyawan, omset dan total neraca (Jahanshahi et al, 2011; Lokhande, 2011; Berisha \& Pula, 2015). Undang-undang Nomor 20 Tahun 2008 membagi UMKM menjadi 4 kriteria yaitu Usaha Mikro, Usaha Kecil, Usaha Menengah, dan Usaha Besar. Adapun, perbedaan selengkapnya dapat dilihat pada gambar 1 berikut (v2cconsultant, 2019).

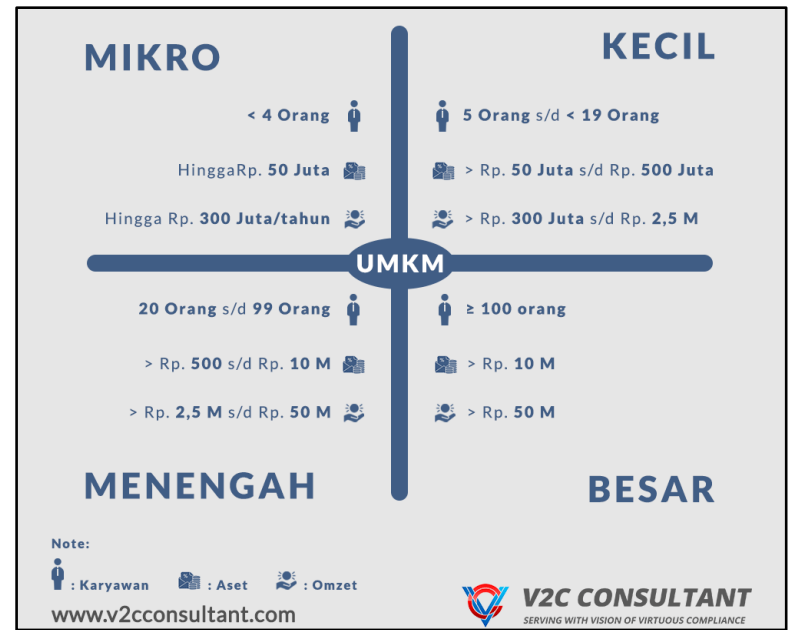

Gambar 1. 4 Kategori UMKM di Indonesia

\section{Metodologi Penelitian}

Metode penelitian yang digunakan dalam penelitian ini adalah deskriptif analisis dan termasuk dalam jenis penelitian kepustakaan. Penelitian ini dilakukan dengan mengkaji data yang bersumber dari data sekunder yaitu data yang diperoleh dari pihak lain, tidak langsung diperoleh peneliti dari subjek penelitian.

\section{Hasil dan Pembahasan}

\section{Dampak Pandemi COVID 19 Terhadap Sektor Ekonomi di Indonesia.}

Sektor ekonomi merupakan salah satu sektor paling berdapak terhadap pandemic covid 19. Banyak masyarakat terkena dampak ekonomi dari pandemi Covid-19, salah satunya sektor usaha yang punyai oleh masyarakat yang secara signifikan jatuh terhadap penjualan mereka. Seperti yang kita ketahui, dunia bisnis dan UMKM merupakan salah satu lokomotif pertumbuhan ekonomi.

Sentra ekonomi seperti mall, restoran, jasa penginapan dan sektor lainnya mengalami kemorosotan daya beli hal ini disebabkan. Pertama, penurunan perdagangan dan investasi internasional di semua negara juga terlihat di menurunnya tingkat produksi dan jasa. Investasi dan perdagangan internasional merupakan faktor utama yang mempengaruhi pertumbuhan ekonomi. Akibatnya, tingkat konsumsi masyarakat juga menurun. Hal inilah yang menyebabkan aktivitas ekonomi pasar melemah.

\section{Pemanfaatan Teknologi di Tengah Pandemi COVID 19}

Pandemi COVID-19 telah memberikan guncangan yang luar biasa dalam perekonomian sektor, termasuk UMKM. Adanya kebijakan pembatasan sosial berskala besar atau PSBB telah membatasi pergerakan orang, yang juga menyebabkan stagnasi di siklus ekonomi masyarakat. Orang-orang akan menahan diri untuk tidak membelanjakan uang mereka karena mereka lebih banyak di rumah. Hal ini tentunya akan berdampak besar bagi UMKM sektor, yang sebagian besar tergantung pada omset ekonomi harian. Oleh karena itu, pemerintah dan pemangku kepentingan lainnya membuat terobosan atau inovasi untuk mengatasi ini. Salah satu aksinya adalah memperkenalkan konsep digital marketing dengan memanfaatkan kemajuan teknologi informasi seperti internet untuk sektor UMKM pemain. Penelitian yang dilaporkan pada akhir Januari 2020 mengungkapkan bahwa jumlah Pengguna 
internet di Indonesia telah mencapai 175,4 juta, sedangkan total penduduk Indonesia sekitar 272,1 juta. Jumlah ini mengalahkan rata-rata dunia yang hanya 6 jam 43 menit sehari di Internet. Pertumbuhan pemasaran digital di seluruh dunia tidak lepas dari perkembangan internet dan berbagai saluran media sosial. Kapan Facebook membuka pintunya untuk masyarakat umum pada tahun 2006, dampak media sosial mulai mempengaruhi pengguna dan perusahaan, dan situasi ini terus berlanjut hingga saat ini. Mulai dari musim panas 2013, tiga situs dengan lalu lintas terbanyak adalah Facebook, Google dan YouTube-baik situs jejaring sosial langsung atau situs web dengan jejaring sosial yang solid fitur. Meskipun situs ini tidak tersedia untuk mereka yang berusia di bawah 13 tahun dan ditolak aksesnya di Cina, negara terpadat di dunia, satu dari tujuh orang di dunia adalah saat ini merupakan pengguna aktif Facebook. Pertumbuhan media sosial yang mencolok ini hanya mulai memahami proses dan model bisnis oleh para pemimpin bisnis dan peneliti pemasaran. Ini mempengaruhi bagaimana mereka memulai. Di Indonesia, jumlah pengguna media sosial telah mencapai 160 juta, dan meningkat 8,1 persen atau 12 juta pengguna dibandingkan tahun lalu. Dengan begitu, penetrasi penggunaan media sosial di Indonesia sudah mencapai 59 persen dari total populasi. Filipina adalah negara yang paling banyak membuka media sosial dengan total waktu 3 jam 53 menit per hari. Besarnya penggunaan internet dan media sosial di Indonesia seharusnya menjadi hal yang luar biasa potensi bagi pelaku sektor UMKM untuk dapat memanfaatkannya. Karena ini pengguna internet seperti komunitas global tanpa batas yang seharusnya wilayah pemasaran tersendiri. Penggunaan internet khususnya media sosial dapat menjadi strategi pemasaran yang paling efektif karena biaya produksinya yang minimal dan target pemasaran yang luas dan tidak terbatas. Sejalan dengan perkembangan berbagai social aplikasi media, sektor UMKM juga memiliki akses ICT yang mudah. Apalagi dengan teknologi berbasis web 2.0 yang memudahkan pembuatan konten buatan pengguna. Menurut Kaplan \& Haenlein (2010), media sosial dapat dikelompokkan menjadi: sedikitnya enam jenis, yaitu:
1) Situs web yang memungkinkan pengguna untuk mengubah, menambah, atau menghapus konten di situs web

2) Blog atau blog mikro yang membebaskan penggunanya untuk mengekspresikan sesuatu di blog.

3) Konten adalah aplikasi yang memungkinkan pengguna untuk berbagi informasi (konten) dalam berupa video, ebook dan gambar, misalnya YouTube, Instagram.

4) Situs jejaring sosial adalah aplikasi yang menghubungkan pengguna jejaring sosial

5) situs jaringan untuk menghubungkan dan berbagi informasi, baik publik maupun pribadi informasi, misalnya Facebook.

6) Dunia game virtual adalah aplikasi yang memungkinkan pengguna untuk mereplikasi lingkungan dalam bentuk tiga dimensi (3D) untuk berinteraksi dengan orang lain sebagaidi dunia nyata, contoh aplikasi ini adalah game online.

Dunia Sosial Virtual yang memiliki konsep yang hampir sama dengan dunia maya dunia game tetapi dalam konteks yang lebih bebas, misalnya, adalah aplikasi kehidupan kedua. Munculnya media sosial jelas merupakan peluang yang sangat positif bagi usaha kecil dan usaha menengah, khususnya karena tidak membutuhkan modal yang besar sumber daya untuk dapat memanfaatkan media sosial dan berbagai keuntungan yang dapat diperoleh jika Anda dapat memanfaatkannya secara optimal. Ruang lingkup sektor UMKM adalah umumnya terbatas hanya pada wilayah dimana UMKM itu berada, tetapi dengan media, tidak ada lagi batasan pemasaran barang atau jasa. UMKM akan menggunakan forum, blog, komunitas, dan saluran sosial lainnya untuk berkreasi kemitraan dengan konsumen, vendor, dan pemangku kepentingan utama lainnya. salah satu dari Manfaat terbesar menggunakan media sosial bagi perusahaan adalah para pebisnis dapat menarik minat berbagai macam pelanggan dengan biaya yang relatif rendah media tradisional. Evisiensi ini adalah pemikat utama yang dapat dibawa oleh media social pemilik bisnis, terutama pendatang baru dengan sumber daya minimal. Sebagai perbandingan, penggunaan media sosial masih sangat nyaman dan memiliki aksesibilitas yang tinggi. 
Studi Harto et al (2019) menunjukkan bahwa penggunaan media sosial di kalangan kecil dan bisnis menengah cenderung meningkatkan volume pendapatan. Pertumbuhan pendapatan terutama dirasakan oleh usaha kecil dan menengah sebesar 15-20 persen. ini di sejalan dengan temuan penelitian lain yang menyatakan bahwa media sosial adalah pemasaran alat untuk barang atau jasa selain platform untuk keterlibatan konsumen untuk mencoba memecahkan masalah mereka sendiri. Berdasarkan temuan pengamatan pada MMEP dan platform yang digunakan, MMEP telah mampu meningkatkan pendapatan lebih dari 100 persen sejak mereka menggunakan media sosial sebagai pelopor komunikasi pemasaran dan informasi bagi MMEP. Selain itu, perusahaan kecil hingga menengah ini sering memperbarui produk dan informasi bisnis secara berkala. Sementara itu, kecil dan menengah bisnis telah meningkatkan pendapatan kurang dari 50\%, terutama karena relatif jarang memperbarui detail pada pembaruan mingguan dan bahkan bulanan. Secara teoritis harus diakui bahwa ada berbagai manfaat yang dapat diperoleh diperoleh dari keterlibatan pelaku UMKM dalam format ekonomi digital. Selain dapat mendongkrak keuntungan finansial melalui peningkatan penjualan online dan memberikan keuntungan bagi pembeli dengan kesempatan untuk menghemat $11 \%-25 \%$ dari retail harga yang tak kalah penting, digitalisasi UMKM juga akan membuka ruang baru yang dapat mencegah UMKM kolaps akibat krisis ekonomi.

\section{Kesimpulan}

Hasil kajian pustaka menyimpulkan bahwa pandemi virus corona berdampak signifikan terhadap pelaku usaha di seluruh dunia termasuk di Indonesia. Sebagian besar pelaku usaha terpaksa menghentikan usahanya kegiatan, karena kebijakan yang dikeluarkan oleh pemerintah. Keadaan ini berdampak pada penurunan turnover. Tapi di Disisi lain terjadi peningkatan yang signifikan dalam transaksi penjualan online sehingga dapat menjadi peluang untuk pertumbuhan UMKM dengan mengoptimalkan pemasaran online.

\section{Ucapan Terima Kasih}

Ucapan terima kasih peneliti kepada Deputi Bidang Penguatan Riset dan Pengembangan Kementerian Pendidikan, Kebudayaan, Riset, dan Teknologi sebagai penyandang dana penelitian pada skema Penelitian Dosen Pemula (PDP) tahun 2021, dan tidak lupa pula kepada LLDIKTI Wilayah XIII Provinsi Aceh serta LPPM AMIK Indonesia yang telah membimbing sehingga hasil penelitian sesuai dengan harapan, dan tidak lupa pula kepada Civitas Akademi AMIK Indonesia serta stackholder yang telah membimbing selesainya hasil penelitian ini.

\section{Daftar Pustaka}

Aliyyah, R. R., Rachmadtullah, R., Samsudin, A., Syaodih, E., Nurtanto, M., \& Tambunan, A. R. S. (2020). The perceptions of primary school teachers of online learning during the COVID-19 pandemic period: A case study in Indonesia. Journal of Ethnic and Cultural Studies, 7(2), 90-109.

Berisha, G., \& Pula, J. S. (2015). Defining Small and Medium Enterprises: a critical review. Academic Journal of Business, Administration, Law and Social Sciences, 1(1), 17-28.

Bostanshirin, S. (2014, September). Online marketing: challenges and opportunities. In Proceedings of SOCIOINT14-International Conference on Social Sciences and Humanities, Istanbul, September (pp. 8-10).

Ciotti, M., Ciccozzi, M., Terrinoni, A., Jiang, W. C., Wang, C. B., \& Bernardini, S. (2020). The COVID-19 pandemic. Critical reviews in clinical laboratory sciences, 57(6), 365-388.

Galhotra, B., \& Dewan, A. (2020, October). Impact of COVID-19 on digital platforms and change in E-commerce shopping trends. In 2020 Fourth International Conference on I-SMAC (IoT in Social, Mobile, Analytics and Cloud)(I-SMAC) (pp. 861866). IEEE. 
Jahanshahi, A. A., Nawaser, K., Sadeq Khaksar, S. M., \& Kamalian, A. R. (2011). The relationship between government policy and the growth of entrepreneurship in the micro, small \& medium enterprises of India. Journal of technology management \& innovation, 6(1), 66-76.

Kim, R. Y. (2020). The impact of COVID-19 on consumers: Preparing for digital sales. IEEE Engineering Management Review, 48(3), 212-218.

Lokhande, M. A. (2011). Financial Inclusion: Options for Micro, Small and Medium Enterprises. Synergy (0973-8819), 9(2).

Opreana, A., \& Vinerean, S. (2015). A new development in online marketing: Introducing digital inbound marketing. Expert Journal of Marketing, 3(1).

Pantelimon, F. V., Georgescu, T. M., \& Posedaru, B. S.. (2020). The impact of mobile e-commerce on gdp: A comparative analysis between romania and germany and how covid-19 influences the $e$ commerce activity worldwide. Informatica Economica, 24(2), 27-41.

Patrutiu-Baltes, L. (2016). Inbound Marketingthe most important digital marketing strategy. Bulletin of the Transilvania University of Brasov. Economic Sciences. Series $V, 9(2), 61$.

Pfefferbaum, B., \& North, C. S. (2020). Mental health and the Covid-19 pandemic. New England Journal of Medicine, 383(6), 510-512.

Rodriguez-Morales, A. J., Bonilla-Aldana, D. K., Tiwari, R., Sah, R., Rabaan, A. A., \& Dhama, K. (2020). COVID-19, an emerging coronavirus infection: current scenario and recent developments-an overview. J Pure Appl Microbiol, 14(1), 512.
Simonetti, A., Pais, C., Jones, M., Cipriani, M. C., Janiri, D., Monti, L., ... \& Sani, G. (2020). Neuropsychiatric symptoms in elderly with dementia during COVID-19 pandemic: definition, treatment, and future directions. Frontiers in psychiatry, 11.

Sultan, S., Lim, J. K., Altayar, O., Davitkov, P., Feuerstein, J. D., Siddique, S. M., ... \& ElSerag, H. B. (2020). AGA rapid recommendations for gastrointestinal procedures during the COVID-19 pandemic. Gastroenterology, 159(2), 739758.

Sverzellati, N., Milanese, G., Milone, F., Balbi, M., Ledda, R. E., \& Silva, M. (2020). Integrated radiologic algorithm for COVID-19 pandemic. Journal of thoracic imaging.

Tosepu, R., Gunawan, J., Effendy, D. S., Lestari, H., Bahar, H., \& Asfian, P. (2020). Correlation between weather and Covid-19 pandemic in Jakarta, Indonesia. Science of the total environment, 725, 138436.

v2cconsultant. (2019). 4 Kategori UMKM di Indonesia, Usaha Anda termasuk yang mana?. URL: https://www.v2cconsultant.com/en/new s-detail/4-kategori-umkm-di-indonesiausaha-anda-termasuk-yang-mana-221. Diakses Tanggal 25 Mei 2021 (22:45). 